\title{
Seismic performance of brick masonry infilled frame structures with bed joint reinforcements
}

\author{
Maidiawati ${ }^{1, *}$, Jafril Tanjung ${ }^{2}$, Yulia Hayati $^{3}$, Agus $^{1}$, and Satria Rangga $^{1}$ \\ ${ }^{1}$ Civil Engineering Department, Padang Institute of Technology, West Sumatera, Indonesia \\ ${ }^{2}$ Civil Engineering Department, Andalas University, West Sumatera, Indonesia \\ ${ }^{3}$ Civil Engineering Department, Syiah Kuala University, Banda Aceh, Indonesia
}

\begin{abstract}
This paper presents the evaluation of the seismic performance of brick infilled RC frame structures with bed joint reinforcements based on reversed cyclic lateral load tests. Three specimens of the structural model of $1 / 4$ scale-down single-story single-bay brick infilled RC frame was prepared, which were brick infilled $\mathrm{RC}$ frames with and without bed joint reinforcements. Two specimens of brick infills with bed joint reinforcements were different in the spacing of bed joint rebars. The specimens were tested by applying a reversed cyclic lateral loading in-plane direction. During the tests, the crack propagation was observed at the peak and residual drifts of each loading cycle to recognize the failure mechanisms of the specimens. As the results, although the use of the bed joint reinforcements ineffective to increase the lateral strength of the overall infilled frame structure. The rebars in mortar bed joints role to sustain the lateral strength in plastic deformation, and provide the whole structure with high ductility. It seemed that the rebars in mortar bed joints confined the brick infills. Therefore, the infilled RC frames can survive in large deformation without failure of the infills in out of the plane direction.
\end{abstract}

\section{Introduction}

Masonry walls are ubiquitously used as infill in reinforced concrete $(\mathrm{RC})$ frame structure buildings in high seismic region. According to post-earthquake observation results, the presence of masonry infills influenced the behavior of RC building during an earthquake $[1,2]$. The results of the previous studies have been summarized that unreinforced brick masonry infill contributes to increase the lateral strength and stiffness but decrease the ductility of infilled RC frame structures [2-5]. However, the brick masonry infill recurrently failed out of the plane direction in many cases of earthquake events [6]. For providing excellent ductility performance on infilled frame structure and preventing the out of the plane failure of masonry infills, several strengthening methods have been developed by researchers such as the use mesh carbon and mesh glass [7], the use passive compression method [8], and reinforcements embedded in mortar bed joints. [9-11].

The use of horizontal rebars placed in mortar bed joints has been commonly used in brick masonry infills of RC buildings. It is presumed that the use of the horizontal rebars as bed joint reinforcements of brick masonry infills may enhance the ductility performance of the brick masonry infilled RC frame structures, effectively control the crack, and reduce the damage inplane and out of plane directions [12]. However, the seismic behavior of masonry infills with horizontal bed joint rebars is still unrevealed clearly. Therefore, a series of experimental studies on single-story single-bay brick infilled $\mathrm{RC}$ frame structures with horizontal rebars placed in mortar bed joints was carried under reversed cyclic lateral load tests. This paper presents the test results comparing the seismic performance between unreinforced brick infilled frames and brick infilled frames with bed joint reinforcements.

\section{Experimental study}

\subsection{Prototype specimens}

In this study, three specimens of $1 / 4$ scale-down singlestory single-bay brick infilled RC frames were constructed. All specimens had the same cross-sectional dimensions and rebars arrangement, which described in Fig. 1(a). The figure shows $750 \mathrm{~mm}$ of the clear height of the columns with $125 \mathrm{~mm} \times 125 \mathrm{~mm}$ of the crosssection dimensions. The longitudinal and transversal reinforcements of columns were 4D10 and $\phi 4 @ 50$, respectively. The dimensions of the lower-beam were $700 \mathrm{~mm}$ wide, $200 \mathrm{~mm}$ deep, and $1650 \mathrm{~mm}$ length with 12D13 longitudinal bars and $\phi 6 @ 50$ transverse stirrups. The dimensions of top-beam were $200 \mathrm{~mm}$ wide, 200 $\mathrm{mm}$ deep, and $1550 \mathrm{~mm}$ length with 4D13 longitudinal bars and $66 @ 50$ transverse stirrups. The three specimens consisted of one brick infilled RC frame (IF-BM), and

\footnotetext{
* Corresponding author: maidiawati@itp.ac.id
} 
two brick infilled frames with bed joint reinforcements (IF-RM-01 and IF-RM-02). On the last two specimens, horizontal reinforcements of $2 \varnothing 6$ were placed in bed mortar joints with rebars spacing of $125 \mathrm{~mm}$ and 250 $\mathrm{mm}$ for the IF-RM-01 and IF-RM-02 specimens, respectively, as shown in Figs. 2(a) and 2(b). Both ends of each rebar were embedded about $2.5 \mathrm{~cm}$ in boundary columns as the shear connector, which glued using a chemical epoxy adhesive.
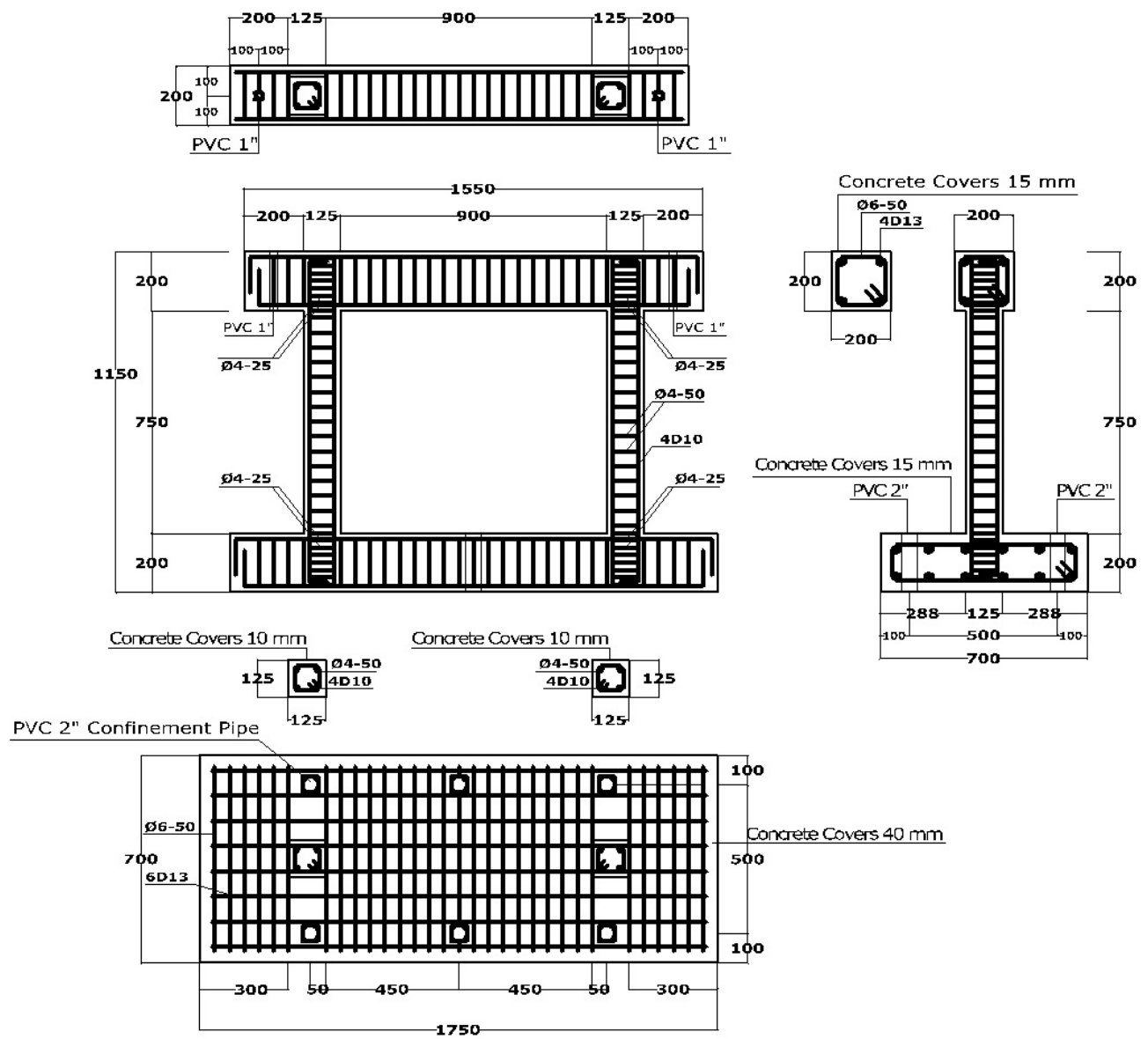

Fig. 1. Cross-section and reinforcements detail of RC frame.

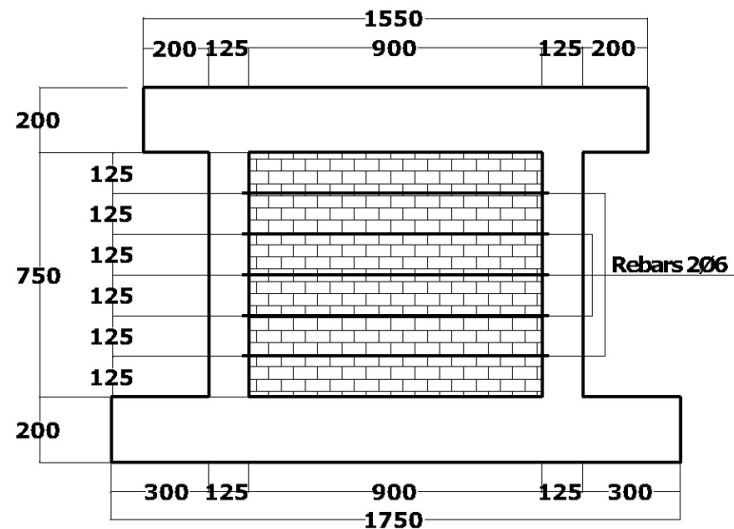

(a) IF-RM-01 specimen

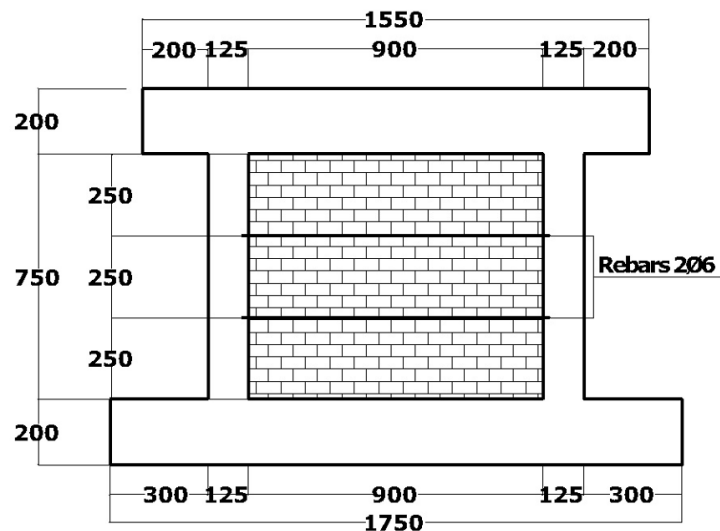

(b) IF-RM-02 specimen

Fig. 2. Design drawing of infilled RC frames with bed joint reinforcements specimens. 


\subsection{Material properties}

The material properties of specimens of the compressive strength of concrete $f c$, the compressive strength of brick masonry prism $f b m$ ', the compressive strength of bed joint mortar fm', the yield and tensile strengths and the young modulus of reinforcements are summarised in Table 1.

Table 1. Material Properties of Specimens.

\begin{tabular}{|c|c|c|c|}
\hline Specimen & $\begin{array}{c}\text { fc' } \\
(\mathrm{N} / \mathbf{m m} 2) \\
\end{array}$ & $\begin{array}{c}\text { fbm' } \\
(\mathbf{N} / \mathbf{m m} 2) \\
\end{array}$ & $\begin{array}{c}\text { fm' } \\
(\mathbf{N} / \mathbf{m m} 2) \\
\end{array}$ \\
\hline IF-BM & 37.32 & 7.80 & 13,9 \\
\hline IF-RM-01 & 37.32 & 7.80 & 13,9 \\
\hline IF-RM-02 & 37.32 & 7.80 & 13,9 \\
\hline \multicolumn{4}{|c|}{ Reinforcing bars } \\
\hline $\begin{array}{c}\text { Bar } \\
\text { number }\end{array}$ & $\begin{array}{c}\text { Yield } \\
\text { strength } \\
(\mathrm{N} / \mathbf{m m} 2)\end{array}$ & $\begin{array}{c}\text { Tensile } \\
\text { strength } \\
(\mathrm{N} / \mathbf{m m} 2)\end{array}$ & $\begin{array}{c}\text { Young } \\
\text { modulus } \\
(\mathrm{N} / \mathrm{mm} 2)\end{array}$ \\
\hline$\varnothing 4$ & 390.19 & 574.90 & $1.70 \times 10^{5}$ \\
\hline$\varnothing 6$ & 346.84 & 446.30 & $1.91 \times 10^{5}$ \\
\hline D10 & 449.50 & 612.20 & $2.62 \times 10^{5}$ \\
\hline D13 & 443.30 & 603.90 & $2.14 \times 10^{5}$ \\
\hline
\end{tabular}

\subsection{Test set up}

The prepared specimens were tested under quasi-static cyclic lateral load in which a schematic view of the test set up and instrumentation are shown in Fig. 3.

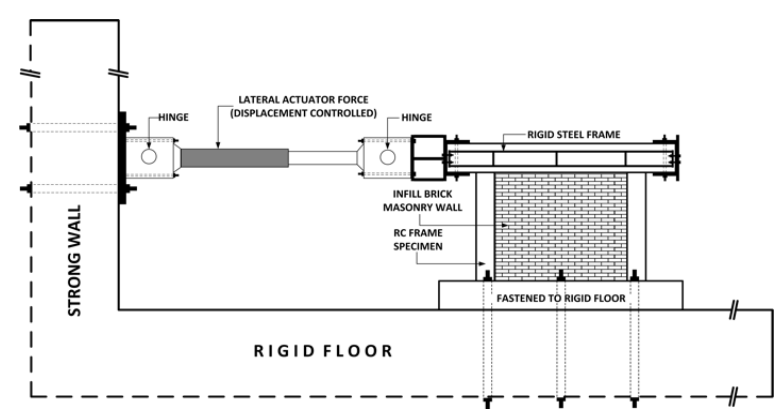

a). The test set up a view.

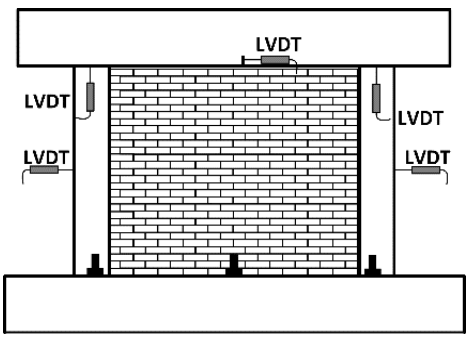

b). The position of the LVDTs

Fig. 3. Experimental test setup and instrumentation.
For the test set up of the specimen, at first, the specimen was placed on the rigid-floor, and then it was fastened to the rigid-floor by using six post-tensioning rods to make the specimen with a fixed support at the lower beam as shown in Fig. 3(a). A double-action lateral actuator force equipment was attached and fastened to the strong wall by using four post-tensioning rods. Two horizontal steel beams were used to restrain the top-beam of the specimen from preventing the applied force on its top-beam causes out-of-plane deformation occurs during testing. These two horizontal steel beams were connected to the actuator force, which mounted on the strong wall. The displacement transducers (LVDTs) were installed at several points to measure the deformation of the $\mathrm{RC}$ frame specimen, as is shown in Fig. 3(b). A displacement transducer which was placed in the middle of top-beam was used as a displacement-control point.

\section{Test method}

According to the FEMA 461 [13], the lateral loading program was employed to specimen with initial cycles to $\mathrm{R}=1 / 800$ followed by two cycles to $\mathrm{R}=1 / 400, \mathrm{R}=1 / 200$, $\mathrm{R}=1 / 100, \mathrm{R}=1 / 50, \mathrm{R}=1 / 25, \mathrm{R}=1 / 12.5$ and the a final load by a pushover to $R=+1 / 10$ rad where $R$ was drift angle that was a ratio of lateral displacement to column height, used for controlling the incremental loading. The lateral loading history applied to specimens is shown in Fig. 4. Incremental of the applied lateral static load and lateral deformation were monitored and recorded throughout the tests. An initial crack and its crack propagation were drawn on the RC frame and brick masonry infill in every loading cycle for identifying the failure mechanism of the specimen.

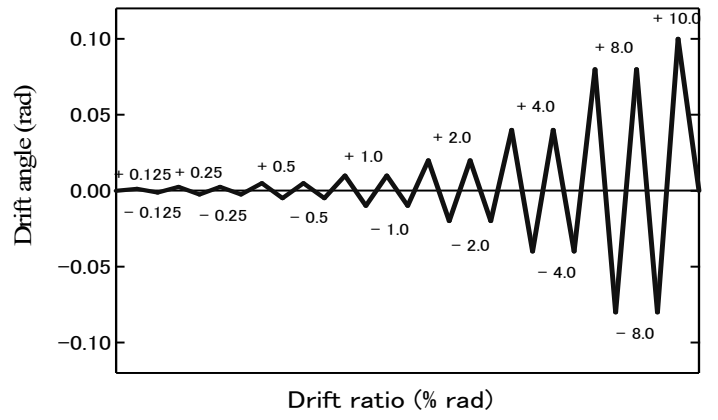

Fig. 4. Lateral loading history.

\section{Experimental results and discussion}

\subsection{Mechanism failure of specimens}

The failure process of three specimens was observed during the experimental works. The initial crack, remarkable cracks, and crack propagation were assessed on the boundary columns, and brick infills every loading cycle and residual drift. The comparison of the failure mechanism between three specimens were presented as follows. 


\subsubsection{IF-BM Specimen}

Under cyclic lateral load on brick infilled RC frame (IFBM) specimen, the initial flexural crack was observed at the bottom of the tensile column in the cycle 1/800 at a drift ratio of $0.13 \%$. The flexural cracks were developed on the bottom of both columns during the cycles of drift angle $1 / 400$. Initial shear crack on the center of brick infill occurred during the cycle $1 / 200$ at a drift ratio of $0.47 \%$. Further, flexural cracks in both columns grown, and shear cracks on infill widened/elongated during the cycles of $1 / 100$. The maximum lateral strength was observed at these cycles. At the next cycles of 1/50, an initial shear crack occurred at the top of the tensile column at a drift ratio of $1.11 \%$, the plaster mortar started to peel off, the shear cracks on the ends of tensile columns were widened, and the lateral strength was gradually degraded. Consequently, the brick infill failed in shear during the cycle $1 / 25$ at a drift ratio of $3.65 \%$. Moreover, the boundary column failed in shear during the cycle 1/12.5, and the brick infill failed in out of plane direction during the cycle 1/10. After the failure of column and brick infill, the lateral strength significantly dropped. The condition of the IF-BM specimen after the cycle of 1/12,5 is shown in Fig. 5(a).

\subsubsection{IF-RM-01 Specimen}

At first loading of the cycle $1 / 800$, it was detected initial shear crack on brick infill, separation crack between column and brick infill, initial flexural at the bottom of the tensile column. During the cycles $1 / 800$, several shear cracks appeared on infill.

The flexural cracks on both columns and shear cracks on infill were grown during the next cycles loading. First, shear crack on the column was detected in the cycle of $1 / 400$ at a drift ratio of $0.24 \%$. Since this cycle, shear cracks on both columns were developed and enlarged. The plaster mortar began to peel off in the cycle $1 / 100$. Consequently, shear failure occurred on brick infill during the cycle $1 / 25$ at a drift ratio of $3.95 \%$. The column failed in shear during the cycles $1 / 12.5$ at a drift $7,2 \%$. At these cycles, it was found out the buckled longitudinal rebar at the bottom column. By the last cycles of $1 / 12.5$, the brick infill with bed joint reinforcements was able to survive from failure in out of the plane direction. Fig 5(b) shows the cracks of the IFRM-01 specimen at the cycle of 1/12.5.

\subsubsection{IF-RM-02 Specimen}

Initial shear crack on brick infill of IF-RM-02 specimen appeared at the first cycle of $1 / 800$ at a drift ratio of $0.05 \%$. Further, in this cycle, an initial flexural crack occurred on brick infill at a drift ratio of $0.12 \%$. During the cycle $1 / 400$, initial flexural and shear cracks were observed on the compressive column and tensile columns, respectively, at a drift ratio of $0.22 \%$. In subsequent cycles, several shear cracks dominantly appeared in the center area of infill, and the plaster of mortar started to peel off during the cycles 1/200. However, the plaster of mortar collapsed during the cycles $1 / 50$, and then brick infill failed in shear, the development of shear cracks on infill was slower when it was compared to brick infill without bed joint reinforcements. Further, the tensile column failed in shear during the cycles $1 / 12.5$ at a drift ratio of $3.9 \%$. After the shear failure of the column, the whole structure dropped its lateral strength to $67 \%$ of the peak, but the infill persisted from out of plane failure. The final condition of the IF-RM-02 specimen at drift angle $\mathrm{R}=1 / 12.5$ is shown in Fig. 5(c).

Based on the crack propagation and failure mechanism of the infilled frame specimens described above, the difference behavior was noticed between of three specimens. Table 2 shows the comparison of the assessed specific cracks in each drift ratio during the loading cycles. The crack propagation on infills with bed joint rebars was slower when it was compared to brick infill without bed joint reinforcements. It seems that the bed joint rebars controlled the crack widened. Besides, the bed joint reinforcements confined the brick masonry infill. Therefore, the brick infills with bed joint rebars can survive in large deformation without failure in out of the plane direction.

\subsection{Lateral strength-drift ratio relationship}

The seismic performance of brick infilled RC frame specimens is presented as a relationship between lateral force and drift ratio, as shown in Fig 6, comparing the seismic performance between the specimens.

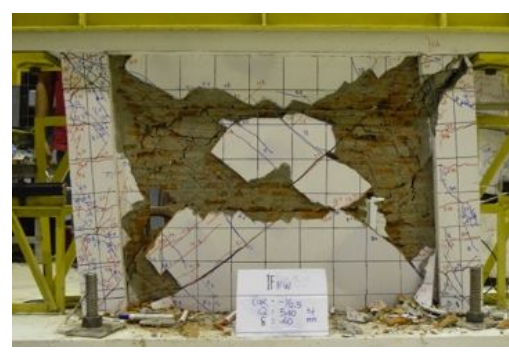

a) IF-BM specimen

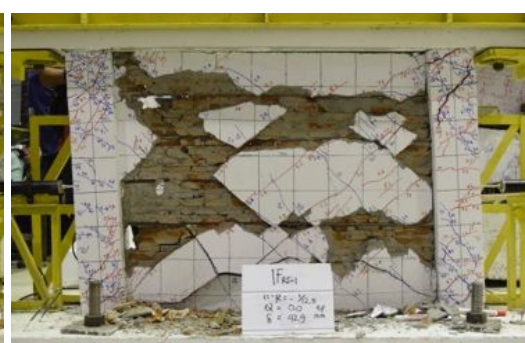

b) IF-RM-01 specimen

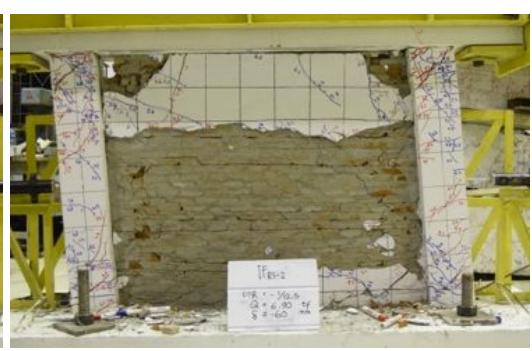

c) IF-RM-02 specimen

Fig. 5. The final condition of specimens a drift angle to $R=1 / 12.5$. 
Table 2. Comparison of major cracks.

\begin{tabular}{|l|c|c|c|c|c|c|}
\hline \multirow{2}{*}{ Assessed cracks/failure } & \multicolumn{2}{|c|}{ IF-BM specimen } & \multicolumn{2}{c|}{ IF-RM-01 specimen } & \multicolumn{2}{c|}{ IF-RM-02 specimen } \\
\cline { 2 - 7 } & $\begin{array}{c}\text { Loading } \\
\text { cycles }\end{array}$ & $\begin{array}{c}\text { Drift } \\
\text { ratio (\%) }\end{array}$ & Loading cycles & $\begin{array}{c}\text { Drift ratio } \\
\text { (\%) }\end{array}$ & Loading cycles & $\begin{array}{c}\text { Drift } \\
\text { ratio (\%) }\end{array}$ \\
\hline $\begin{array}{l}\text { Initial flexural crack on the } \\
\text { column }\end{array}$ & $1 / 800(-1)$ & 0.13 & $1 / 800(-1)$ & 0.13 & $1 / 800(-1)$ & 0.13 \\
\hline Initial shear crack on infill & $1 / 200(+1)$ & 0.47 & $1 / 800(+1)$ & 0.13 & $1 / 800(+1)$ & 0.13 \\
\hline $\begin{array}{l}\text { Initial shear crack on the } \\
\text { column }\end{array}$ & $1 / 50(+1)$ & 2,0 & $1400(+1)$ & 0.25 & $1 / 400(+1)$ & 0.25 \\
\hline Maximum lateral strength & $\mathbf{1 / 0 0}(+\mathbf{1})$ & $\mathbf{0 . 9 9}$ & $\mathbf{1 / 2 0 0}(+\mathbf{1})$ & $\mathbf{0 . 4 3}$ & $\mathbf{1 / 5 0}(-\mathbf{1})$ & $\mathbf{2 . 0 1}$ \\
\hline Shear failure of infill & $1 / 25(-1)$ & 4.0 & $1 / 25(+1)$ & 4.0 & $1 / 25(-1)$ & 4.0 \\
\hline Shear failure of column & $1 / 12.51$ & 8.0 & $1 / 12.5(-1)$ & 8.0 & $1 / 12.5(+2)$ & 8.0 \\
\hline $\begin{array}{l}\text { Out of plane failure of } \\
\text { infill }\end{array}$ & $\mathbf{1 / 1 2 . 5 ( + 2 )}$ & $\mathbf{8 . 0}$ & No failure & - & No failure & - \\
\hline
\end{tabular}

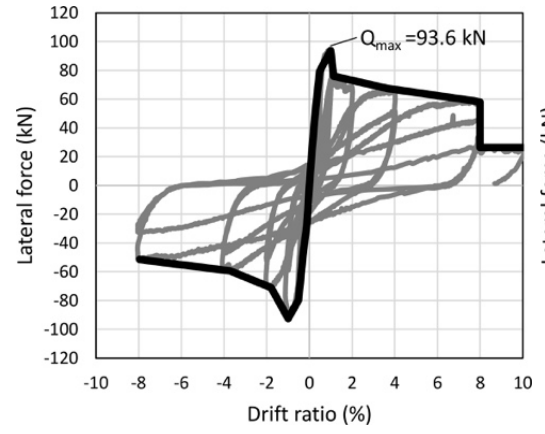

a) IF-BM specimen

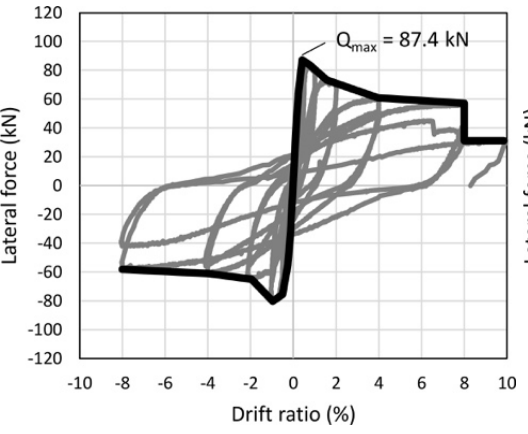

b) IF-RM-01 specimen

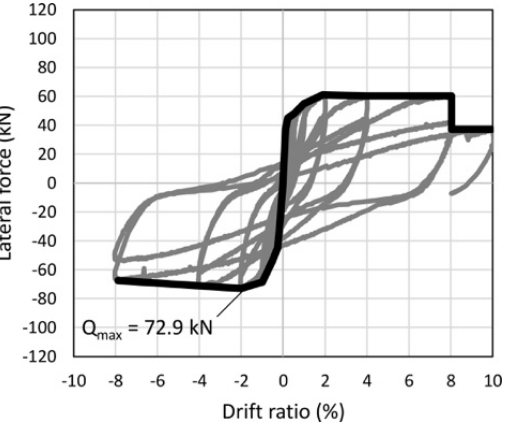

c) IF-RM-02 specimen

Fig. 6. Lateral force - drift ratio relationship

The maximum lateral strength of the IF-BM specimen of $93.6 \mathrm{kN}$ was observed at a $0.99 \%$ drift ratio. On the other hand, the maximum lateral strength of $87.4 \mathrm{kN}$ and 72.9 $\mathrm{kN}$ were observed at $0.43 \%$ and $2.01 \%$ drift ratios for IFRM-01 and OF-RM-02 specimens, respectively. In the case of IF-BM, the maximum lateral strength was reached at the elastic region, and its strength degraded soon after the peak in the plastic region, as shown in Fig. 6(a). After the shear failure of infill at a drift ratio of $4.0 \%$ and column at a drift ratio of $8 \%$, the lateral strength of structure significantly dropped to $28.06 \%$ of peak assumed as a residual strength. However, in the case of the IF-RM-01 specimen, its envelope curve of strength was similar to that of the IF-BM specimen, its residual strength was $31.16 \%$ of the peak, as shown in Fig. 6(b). A distinctive envelope curve of strength was identified on IF-RM-02 specimen when it was compared to that of IF-BM and IF-RM-01 specimens. The maximum lateral strength of IF-RM-02 was detected in the plastic region at a large drift ratio, as described in Table 2, and then it was maintained to a drift ratio of $8 \%$, as shown in Fig. 6(c). The residual seismic capacity of IF-RM-02 specimen was $50.94 \%$ in which it can prevent the structure from collapsing in large deformation. It seemed that the rebars in mortar bed joints role to sustain the lateral strength in plastic deformation and provide the whole structure with high ductility. It looked that rebars in mortar bed joints with a spacing of $1 / 3$ of infill height provided better seismic ductility to infilled RC frame structure.

\section{Conclusions}

A series static cyclic lateral loading test was conducted on a brick infilled RC frame specimen, and two specimens of brick infilled RC frames with mortar bed joint reinforcements which consisted of brick infill with rebars spacing of $125 \mathrm{~mm}$ and infill with rebars spacing of $250 \mathrm{~mm}$. As a result, the presence of bed join reinforcements unaffected to increase the lateral strength. However, it maintained the lateral strength of the whole structure in plastic deformation. Thus the brick infills with bed joint reinforcements were able to survive in large shear deformation without failure in out of the plane direction. It revealed that the horizontal rebars in mortar bed joints produce the structure with high ductility. The infilled RC frames with bed joint reinforcements possessed higher residual strength than those of infill RC frame without bed joint reinforcements. 
This research was financially supported by the Ministry of Research, Technology and Higher Education, Indonesia (326/27.O10.5/PN/II/2019). The authors sincerely acknowledge to Civil Engineering Department, Syiah Kuala University, head and staff of Structure and Construction Material Laboratory, Engineering Faculty, Syiah Kuala University, for supporting during prepared the specimens, provided the structural testing facilities and conducted the structural tests.

\section{References}

1. Maidiawati, Y. Sanada, JAABE, 7, 2 (2008)

2. Maidiawati, Y. Sanada, Earthquake Engng Struct. Dyn, 46, 2 (2017)

3. Maidiawati, Y. Sanada, D. Konishi, J. Tanjung, JAABE, 10, 1 (2011)

4. J. Tanjung, Maidiawati, IJCIET, 8, 10 (2017)

5. Arton D., Dautaj, Q. Kadiri, N. Kabashi, j.engstruct, 165 (2018)
6. A. Furtudo, N. Vila-Pouca, H. Varum, A. Arede, Building, 9, 39 (2019)

7. Martins, A., Vasconcelos G., Fangueiro R., Cunha F., International Masonry Society

8. Y. Hayati, Y. Sanada, J. Struct. Constr. Eng., AIJ, 79, 702 (2014)

9. G.M. Calvi, D. Bolognini, Journal of Earthquake Engineering, 5, 2 (2001)

10. A. Piekarczyk, IOP publishing, Material and Engineering, 245 (2017)

11. Maidiawati, J. Tanjung, Y. Hayati, Agus, H. Medriosa, International Journal of Geomate, 16, 57 (2019).

12. A. Penna, G.M. Calvi, D. Bolognini,eds. (2007)

13. FEMA 461 (2007), pp. 21-25. 